\title{
Myths and Realities of Innovative China the Case of Haier Company
}

\author{
Farrukh Nawaz Kayani (Corresponding author) \\ Assistant Professor, Department of Management Sciences \\ COMSATS Institute of Information Technology, Islamabad \\ E-mail: farrukhkayani@comsats.edu.pk
}

Saquib Yusaf Janjua

Assistant Professor, Department of Management Sciences

COMSATS Institute of Information Technology, Islamabad

E-mail: saqib.yousaf@comsats.edu.pk

\author{
Babar Wasim \\ Assistant Professor, Department of Management Sciences \\ COMSATS Institute of Information Technology, Wah \\ E-mail: baburwasim@yahoo.com
}

Received: July 6, 2013 Accepted: July 19, 2013

doi:10.5296/ber.v3i2.3961 URL: http://dx.doi.org/10.5296/ber.v3i2.3961

\begin{abstract}
It is well recognized phenomenon that innovations are a strategic weapon for economic growth and have played an important role in industrialization process of developing countries. Because of the conventional thought that China produces sub-standard goods; the term innovative China sounds like a myth. In reality China has made tremendous progress in producing innovated goods. To support this view, in this paper, we have thoroughly discussed the case of Haier Company. Haier is one of the very successful stories of Chinese companies which absorbed the foreign technology and climbed up the technological ladder. This case of Haier
\end{abstract}


supports our notion of innovation philosophy behind success of world renown Chinese companies.

Keywords: China, Innovation, Case Study, Developing Countries, Haier

\section{Introduction}

The enormous growth of Chines economy in last of couple of decades have grasped attention of academicians and practitioners. They are curious to understand the reasons and factors behind this formidable growth and progress of Chinese companies. In 1978, the Chinese government decided to move away from Soviet-style economic policies in order to gradually reform the economy towards free market principles. In this regard, Chinese government encouraged import substitution strategies to export promotion policies. They established Social Economic Zones (SEZs) to attract foreign direct investments and facilitated domestic firms. Social Economic Zones are geographically separate small areas of a country where governments provide special fiscal and financial incentives to foreign and domestic firms for boosting the exports.

Developing countries offer various kinds of incentive packages to attract Multinational Corporations (MNCs) from developed countries. These incentives are usually divided into "soft" and "hard" ones (Kusago and Tzannatos, 1998). Wong (1987) mentioned that countries establish SEZs for employment creation, technology up-grading and foreign exchange earnings. SEZs as a means of attracting foreign investment and technology along with promoting Chinese exports. By granting special investment incentives to foreign investors, it was hoped that an export-oriented industrial base might be created in the SEZs via foreign capital and technology. Many of these privileges were also extended to domestic firms to encourage their participation in the SEZs and thereby increase their contact with foreign technology and managerial skills.

Aggarwal (2007) has discussed three aspects of SEZs i.e. employment generation, human capital development and technology up gradation. Each aspect exerts two types of effects i.e. direct and indirect. For instance, the employment would be directly generated when the SEZs would hire labor. The indirect employment would be generated through the demand for complementary goods. Similarly, the skill formation effect operates directly when they acquire the skills by working in the SEZs. The spillover effects would take place through the movement of workers to domestic firms. The SEZs would also result into technology transfer to domestic firms.

Johanson and Vahlne $(2003,2001,1977)$ stated that with the increasing internationalization, lots of businesses are emerging on the globe. For firms, to survive and to earn a leading role in the fierce global competitive landscape, unremitting innovations are of immense importance. A number of studies in international business field show that the internationalization of a firm is an incremental process, that is, a firm should gradually increase its international involvement. There are several theories that focus on internationalization process of a firm on "its gradual acquisition, integration and uses of knowledge about foreign markets and operations and on its successively increasing commitment to foreign markets". 


\section{Ml Macrothink}

Business and Economic Research

ISSN 2162-4860

2013, Vol. 3, No. 2

Haier is the single most extensive producer of exhaustive family machines in China. It has developed from minor undertaking to being one of the advancing family apparatuses of China. The philosophy of expansion and internalization of Haier is based on innovation. The paper deliberates on success story of Haier i.e. one the leading Chinese company presence all over the globe. The rest of the paper critically analyzes and discusses the developments and strategy of Haier that make him successful in global competitive environment.

\section{Haier's Historical Development}

Haier group started to work in 1992 by renaming the Qingdao Refrigerator plant which was shaped in 1984. In 1984 an organization together with Liebherr was created following a watchful assessment of 32 potential agreeable confederates. Haier transported in Liebherr's four-star fridge processing innovation and gear to China. Liebherr had 70 years of interaction in generating brilliant fridges. The Chinese features were a few star advances and obsolete-formed with a solidifying ability of -12 degree Celsius. The solidifying ability of Liebherr's four-star innovation was - 18 degree Celsius. Haier ended up being the just Chinese ensemble to give four-star refrigerator mechanics following the partnership with Liebherr.

Following collusion, Haier sent above and beyond 40 of its beat engineers and managers to Liebherr. Liebherr authenticated to be a truly fruitful teaching establishment for Haier's beat R\&D talents. They concentrated on the growth of four-star refrigerator, and possibly aced the crux innovative aptitudes needed for improving progressed fridges. In 1985, a year following it permitted Liebherr's engineering, Haier was fit to present its first four-star icebox in the Chinese business. This feature immediately secured Haier as the advancing refrigerator maker in China. The figure 1, shows tremendous growth of Haier from 2008-2012 in terms of revenue and net income.

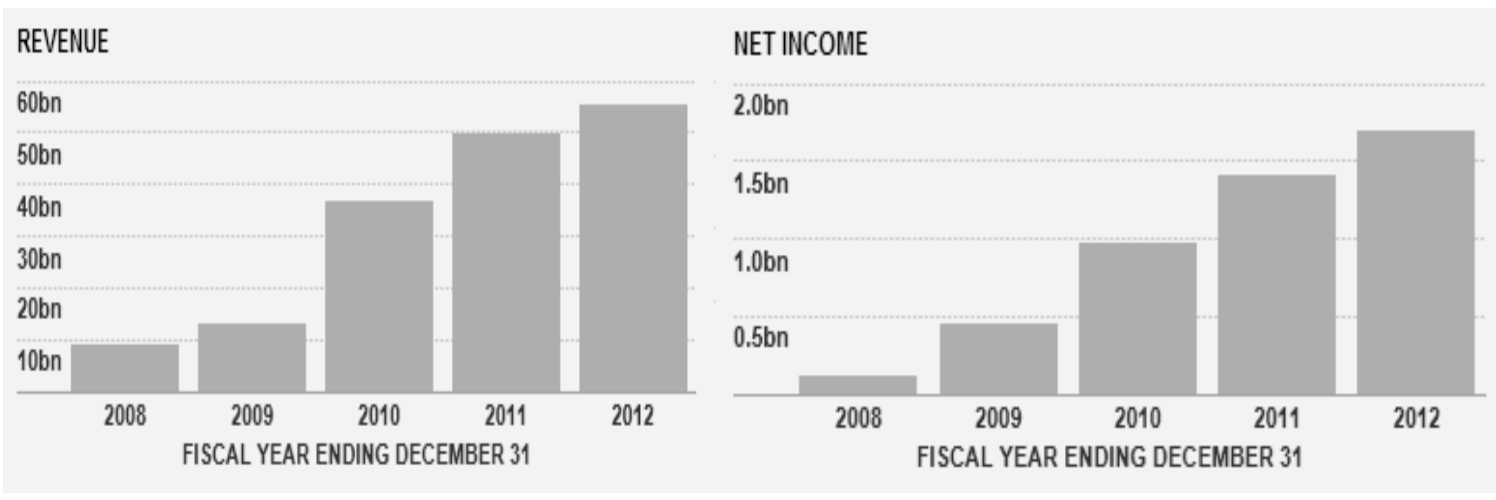

Source: http://markets.ft.com/

Figure 1. Revenue over the time and Net Income over the time (2008-2012)

The overall sale pattern of Haier Electronics Company, for the years 2008 to 2012 is provided along with forecasted sale in the same year as well as for the years 2013 and 2014, is provided in Figure 2. There is upward trend which shows an increase in sales. The forecast till year 2012 is very close to the actual sale, which shows the accuracy of the forecast sales. For the subsequent years after the year 2012, we can expect the same pattern of the Haier's sales. 


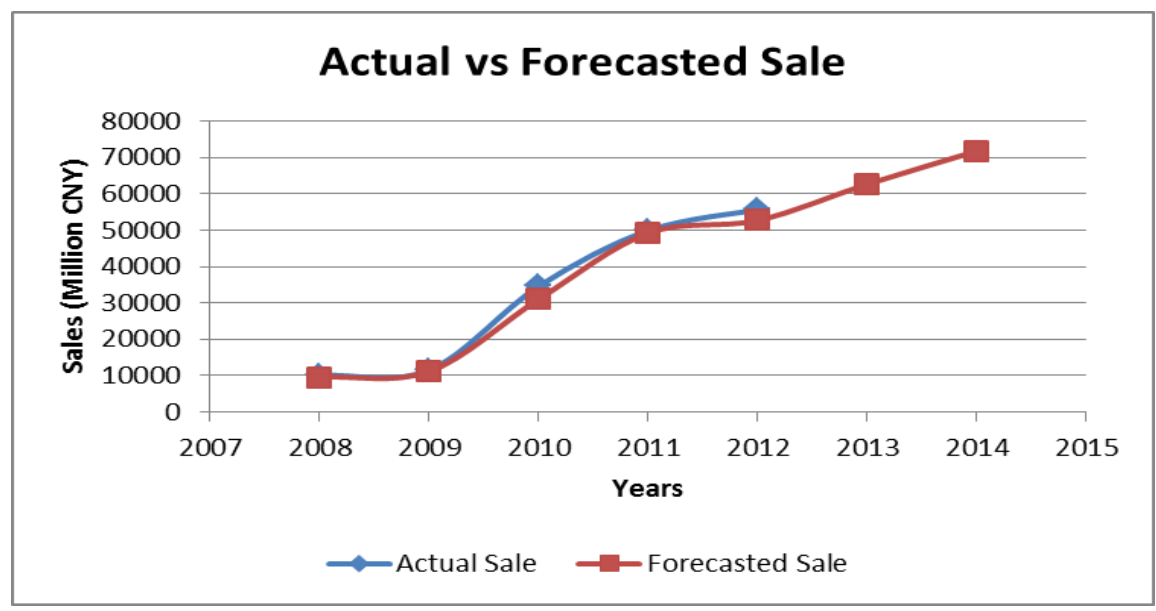

Source: http://www.4-traders.com/

Figure 2. Actual vs Forecasted Annual Sales (2007-2015)

Haier, today makes about 15,100 feature mixed bags in 96 item lines. Over the period of time, Haier has not just upgraded the value but added objective and innovative proficiencies as well. In 1993, nine years following its establishment, Haier was certain enough to start a worldwide operations. The role of present CEO of Haier in upgrading the quality of products is obvious. His order of destruction of 76 defective refrigerators was a symbolic step of moving towards quality production.

In 2003, the Haier brand topped all Chinese trademarks in a nationwide survey. The Chinese Fortune Magazine (issue 8/2004) appraised Haier the second in their catalogue of most obviously appreciated ensembles in China. In this rating Haier was observed as number one in the fields of administration display, development capacity and social obligation. In 2004, Haier was distinguished as one of the World's 100 Most Recognizable Brands in a worldwide name mark post altered by the World Brand Laboratory 10.

As per 2006 Euro-monitor statistics on outfit bargains, Haier has the most extensive planet business sector mark impart for fridges, and it is the fourth right around the worldwide white merchandise makers. Among 2003 and 2006, Haier ranked first in terms of the most part initiative right around terrain Chinese ensembles in the Wall Street Journal Asia's anniversary study of Asia's 200 Most Admired Companies. In 2008, Haier ranked 13th on Forbes' Reputation Institute Global 200 record. In addition in the same year, Haier ranked first around Chinese endeavors on the Financial Times record of the most exceptionally regarded worldwide teams (Duysters et al., 2010). This short article thoroughly discusses the historical development, diversification process and globalization strategies of Haier Company in China.

\section{The Process of Haier's Diversification}

In 1991, Haier started to diversify. Haier also started to produce air-conditioners and freezers besides refrigerators. Haier took three years to establish repute in these two industries. In 1991, the sales and profits of Haier were RMB 724 million and RMB 31.2 million respectively. Whereas in 1994, Haier's sales and profits had grown to RMB 2.56 billion and to RMB 200 million respectively. Subsequently, Haier developed washing machines, microwave ovens and 
water heaters. In 1997, Haier entered into the production of black household appliances. Table 1 summarizes the processes of Haier's diversification over the time.

Table 1. The Stages of Haier's Diversification

\begin{tabular}{|c|l|l|l|}
\hline Stage & \multicolumn{1}{|c|}{ Period } & \multicolumn{1}{c|}{$\begin{array}{c}\text { Diversification } \\
\text { Area }\end{array}$} & \multicolumn{1}{c|}{ Procedure } \\
\hline $\mathbf{1}$ & 1984-Dec 1991 & Refrigerators & $\begin{array}{l}\text { Imported refrigerator technology from Liebherr } \\
\text { Company of Germany. }\end{array}$ \\
\hline $\mathbf{2}$ & Dec. 1991- Jul.1995 & $\begin{array}{l}\text { Freezers } \\
\text { Air-conditioners }\end{array}$ & $\begin{array}{l}\text { Acquired Qingdao Freezer General Plant and Qingdao } \\
\text { Air-conditioner Plant. }\end{array}$ \\
\hline $\mathbf{3}$ & July.1995-Aug.1995 & $\begin{array}{l}\text { Wicrowave ovens } \\
\text { Water Heaters }\end{array}$ & $\begin{array}{l}\text { Acquired Red Star Electric Appliance Factory and } \\
\text { established a joint venture with Laiyang of Shandong } \\
\text { Household Appliance General Plant. }\end{array}$ \\
\hline $\mathbf{5}$ & Sept. 1997 & $\begin{array}{l}\text { Black household } \\
\text { Appliances }\end{array}$ & $\begin{array}{l}\text { Established a joint venture with West Lake of Hangzhou } \\
\text { Electric Group. }\end{array}$ \\
\hline
\end{tabular}

Source: Sun (2002) Yan and Hu (2001) and Duysters et al.(2010)

With the idea of "customers as the foundation of growth", Haier furnishes a one-stop star aid to its clients. In a joint review directed by the China Consumer Association and the China Enterprise Research Centre of Tsinghua University on China's domesticated sturdy items for 2003 and 2004, eight of Haier's feature classifications were ranked No. 1 for client fulfillment and for the most part fulfillment. Notwithstanding excellent home apparatuses, Haier is additionally centered on offering greatest-of-breed aid answers to its clients. Haier's aid framework runs all through the preparation method from item plan, preparation, assembling, to pre-deal, under deals and following deals fix. Inasmuch as 2002, Haier has efficaciously secured an arrangement of over 5,000 household pro aid suppliers to transport auspicious redid utility.

\section{Internationalization Strategies}

Haier is the first Chinese firm to buy a fridge production line in the European Household apparatus segment. It made the first European acquisition in 2001 by getting refrigerator manufacturing plant in Italy. The reason for this acquisition is to enhance range and production capacity. Haier has several abroad modern points of production and sales in the United States, Pakistan and Jordan. In particular, it has 30 abroad plants and 58,800 deals executors worldwide. It sends out its items to more than 130 nations in Europe, Asia, Middle East and North America. The predominant production plant of Haier was in Yugoslavia under a joint venture with a neighborhood community. Haier is transforming coolers, freezers, clothes washers, dishwashers, microwave broilers and modest machines for the European business. In 
Asia, it has engaged in the business sectors of Indonesia, Philippine, Malaysia, United Arab Emirates, Algeria, Bangladesh and Iran through joint ventures. Table 2 below shows the foreign operations of Haier internationally.

Table 2. Foreign Operations of Haier

\begin{tabular}{|l|l|l|l|l|l|}
\hline North America & Europe & South Asia & ASEAN & Middle East Africa \\
\hline USA & Germany & India & Thailand & Jordan & Tunisia \\
\hline & Italy & Pakistan & Indonesia & & Nigeria \\
\hline & Holland & Bangladesh & Philippines & & Egypt \\
\hline & Denmark & Sri Lanka & Malaysia & & Algeria \\
\hline & Romania & & & & South Africa \\
\hline & Ukraine & & & & \\
\hline
\end{tabular}

Haier has devised a few guidelines for its globalization policy. Under this guideline, one-third of its features are both handled and sold in its home nation and the other on one-third of the items are handled in home nation but sold abroad, and rest of the items are both handled and sold abroad. In worldwide extension procedure, Haier's method is to move from challenge to simplicity i.e. dropping in additional propelled business sectors first. It is vital to drop in the more progressed businesses first with a specific end goal, which is to increase more brand recognition.

In the European Union, Haier entered in the German business sector first. Germany is recognized as a troublesome business sector to enter in. Scrutinize systems possess a foremost place in the development and innovative advancements of any immovable. In this respect Haier has engaged in accommodating scrutinize systems with acclaimed unfamiliar firms. The proposed helpful systems furnish Haier qualified information about global slants in innovation improvement. Haier's worldwide mechanics cooperation compass Tokyo, Los Angeles, Montreal, Lyons, Seoul, Sydney and Amsterdam. The accommodating associates of Haier incorporate Toshiba, Mitsubishi, ESS, Philips, Metz and Lucent.

\section{Discussion}

Haier's success lies in the careful positioning of the products rather than only selling its products at the lowest possible prices. The products that accommodate the local specificities were made along with the identification of the niche markets. They are a lot of examples where Haier's products accommodated the local requirements. In Indonesia, Haier presented power saving adaptable-voltage apparatuses due to nation's capacity deficiencies and voltage variances. Haier presented a fridge with fold-out table in United States so as to target the scholars who are residing in dorms. Similarly in Pakistan, they modify their cooling machines to make them adaptable and efficient to extreme weather and electricity load shedding.

In China, Haier advanced a clothes washer that washes both the garments and vegetables. This model is offered to target the people of country territories. In France and Italy, Haier first sold out the iceboxes in light of strategic explanation. As the ventilation system business sector being comparatively a brand new mark was not imperative. The different item lines for 
example iceboxes and clothes washers were presented later following making its mark. Haier additionally presented brand new classes of products similarly as wine cellar room for American market. Initially, Haier confronted great challenge in influencing the clients regarding the handiness of this feature but later on this item has a tremendous demand in the American businesses. In nutshell, the secret of great success of Chines company lies in its innovation philosophy and localization strategy of product features and branding compaign.

\section{Conclusion}

The products of Haier are sold in over 100 nations. The sales of Haier's production are about RMB 118 billion and it employees more than 50,000 workers across the world. Haier with its innovation spirit is a pioneer of Chinese enterprises globalization and brand building. It has emerged into a hefty multinational corporation, and it keeps on expanding its business in China as well as in abroad, such as North America, Europe, and Asia. Over the passage of time, Haier has advanced a noteworthy international R\&D system. The ambitiousness of Haier's plan is reflected in its innovation target: two successful intellectual patent applications every work day that dispel the image of substandard products and reverse re engineering approach of Chinese business counterparts.

\section{References}

Aggarwal, A. (2007). Impact of Social Economic Zones on Employment, Poverty and Human Development Indian Council for Research on International Economic Relations, Working Paper No 194.

Duysters, G., Jo, J., Charmianne, L., \& Yu, J. (2010). "Internationalization and Technological Catching up of Emerging Multinationals: A Comparative Case Study of China's Haier Group", Industrial and Corporate Change, 18(2), 325-349. http://dx.doi.org/10.1093/icc/dtp006

Johanson, J., \& Vahlne, J. E. (1977). The Internationalization Process of the Firm: A Model of Knowledge Development and Increasing Foreign Market Commitments, Journal Of International Business Studies, 8(1), 32-44. http://dx.doi.org/10.1057/palgrave.jibs.8490676

Johanson, J., \& Vahlne, J. E. (2001). “The Mechanism of Internationalization”, International Market Review, 7(4), 11-24.

Johanson, J., \& Vahlne, J. E. (2003). "Business Relationship Learning and Commitment in the Internationalization Process", Journal of International Entrepreneurship, 1, 83-101. http://dx.doi.org/10.1023/A:1023219207042

Kusago, T, \& Tzannatos Z. (1998). Export Processing Zones: A Review in need of Update, Social Protection Discussion Paper No 9802.

Sun, J. (2002). The Company Strategy of Haier, The Enterprise Management Press, China: Beijing.

Yan, J., \& Hu, H. (2001), China’s Haier. Hainan of China Press: Haikou. 


\section{Copyright Disclaimer}

Copyright reserved by the author(s).

This article is an open-access article distributed under the terms and conditions of the Creative Commons Attribution license (http://creativecommons.org/licenses/by/3.0/). 